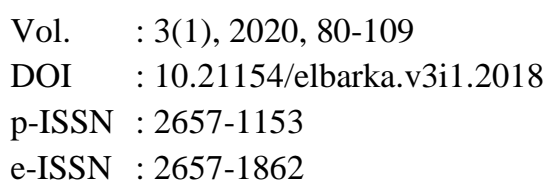

\title{
ALTERNATIF STRATEGI PENANGANAN DAMPAK EKONOMI COVID-19 PEMERINTAH DAERAH JAWA TIMUR PADA KAWASAN AGROPOLITAN
}

\author{
Husna Ni'matul Ulya \\ Institut Agama Islam Negeri Ponorogo \\ Email: husna@iainponorogo.ac.id
}

\begin{abstract}
The COVID-19 pandemic had a significant impact on the order of life of the world community, including in Indonesia. Besides health impacts, the pandemic also has economic impacts, so that it encourages the government to make various policies to overcome these impacts, including by forming task forces both at the central and regional levels. Policy by optimizing state and regional budgets for the needs of preventing the spread and handling of COVID-19 health impacts and optimizing the potential of the local economy for meeting the needs of the community in a sustainable manner. East Java is a superior area in agriculture which includes animal husbandry, fisheries, plantations, and forestry. One of the programs implemented is the development of agropolitan areas which are agricultural-based economic development in agribusiness areas, designed and implemented by synergizing the various potentials that exist to encourage the development of competitive, populist-based, sustainable and decentralized agribusiness business systems. and facilitated by the government. This study uses a literature study approach with the aim of exploring alternative East Java government policies in order to address the economic impact of COVID-19 by maximizing the agropolitan area. The results of the research resulted in the formulation by maximizing the development of the agropolitan area by strengthening regulations and expanding the agropolitan area to other regions / cities, and utilizing online media in the implementation
\end{abstract}


including the marketing system of products from this agropolitan area even though it was in a pandemic.

Keywords: COVID-19, Regional Economic Growth, Agropolitan, Online marketing.

Abstrak: Pandemi COVID-19 memberikan dampak yang signifikan terhadap tatanan kehidupan masyarakat dunia termasuk di Indonesia. Selaian dampak kesehatan, pandemi juga memberikan dampak ekonomi, sehingga medorong pemerintah untuk membuat berbagai kebijakan untuk menanggulangi dampak tersebut, diantaranya adalah dengan membentuk satuan tugas baik di pusat maupun daerah. Kebijakan dengan mengoptimalkan anggaran negara dan daerah untuk kebutuhan pencegahan penyebaran dan penanganan dampak kesehatan COVID-19 dan optimalisasi potensi ekonomi lokal untuk pemenuhan kebutuhan masyarakat secara berkelanjutan. Jawa timur merupakan daerah yang unggul di bidang pertanian yang meliputi peternakan, perikanan, perkebunan, dan kehutanan. Salah satu program yang dijalankan adalah pengembangan kawasan agropolitan yang merupakan pembangunan ekonomi berbasis pertanian di kawasan agribisnis, dirancang dan dilaksanakan dengan cara mensinergikan berbagai potensi yang ada untuk mendorong berkembangnya sistem usaha agribisnis yang berdaya saing, berbasis kerakyatan, berkelanjutan dan terdesentralisasi, serta digerakan oleh masyarakat dan difasilitasi pemerintah. Penelitian ini menggunakan pendekatan studi literatur dengan tujuan untuk menggali alternatif kebijakan pemerintah Jawa Timur dalam rangka menangani dampak ekonomi COVID-19 dengan memaksimalkan kawasan agropolitan. Hasil Penelitian menghasilkan fomulasi dengan memaksimalkan pengembangan kawasan agropolitan dengan penguatan regulasi serta perluasan kawasan agropolitan ke wilayah/kota lain, dan memanfaatkan media online di dalam pelaksanaan termasuk sistem pemasaran produk dari kawasan agropolitan ini meskipun sedang dalam masa pandemi.

Kata Kunci: COVID-19, Pertumbuhan Ekonomi Daerah, Agropolitan, Pemasaran Online. 


\section{PENDAHULUAN}

COVID-19 adalah kepanjangan dari sebuah pandemi coronavirus disease 2019. Penyakit menular dan mematikan yang disebabkan oleh SARSCoV-2, salah satu jenis dari koronavirus. Virus ini pertama kali diumumkan kepada masyarakat dunia pada tanggal 1 Desember 2019 di China, tepatnya di daerah Wuhan Provinsi Hubei, China. Sejak munculnya tanggap darurat yang diumumkan oleh pemerintah Indonesia terkait penyebaran virus COVID-19, maka banyak kebijakan pemerintah pusat maupun daerah yang dilaksanakan untuk tindakan pencegahan (Tim Penulis UGM, 2020). Sampai tanggal 19 Mei 2020 kasus positif COVID-19 di Indonesia sebanyak 18.010 orang, jumlah sembuh 4324 orang dan meninggal 1191 orang, dimana di jawa timur kasus positif berjumlah 1673 (73,35\%), kasus sembuh sebanyak $375(16,44 \%)$ dan meninggal sebanyak $224(9,82 \%)$, angka tersebur menunjukkan bahwa provinsi jawa timur termasuk daerah yang banyak memiliki kasus positif COVID-19.

Presiden RI Joko Widodo, juga telah mengumumkan kasus pertama positif COVID-19 di Indonesia pada Senin, 2 Maret 2010 yang ditularkan melalui transmisi dari manusia ke manusia. Berbagai upaya telah dilakukan oleh pemerintah RI, salah satunya dengan membentuk Gugus Tugas Percepatan Penanganan COVID-19 yang disahkan melalui Keputusan Presiden RI No.7 Tahun 2020, yang kemudian diperbaharui melalui Keputusan Presiden RI No.9 Tahun 2020. Adapun tujuan dari Gugus Tugas ini adalah meningkatkan ketahanan nasional dibidang kesehatan, meningkatkan sinergi antar kementerian/lembaga dan pemerintah daerah, antisipasi eskalasi peyebaran dan meningkatkan kesiapan, kemampuan dalam mencegah, 
emndetesi dan merespon COVID-19 (Tim Penulis Gugug Tugas, 2020). Pemerintah telah memberlakukan pada beberapa kota di jawa timur, yaitu Surabaya, Sidoarjo, Malang, dan Gresik untuk melakukan Pembatasan Sosial Berskala Besar (PSBB) (jatimprov.go.id), dimana PSBB tersebut adalah adalah untuk melandaikan kurva dengan membatasi penyebarannya. Pemerintah daerah dapat menerapkan PSBB atas persetujuan Menteri Kesehatan dengan mengikuti Pedoman PSBB (Peraturan Menteri Kesehatan Nomor 9 Tahun 2020) (Bnpb.go.id).

Akibat penyebaran COVID-19 menyebabkan dampak seperti pada bidang pekerjaan yang banyak dilakukan PHK, perubahan perilaku masyarakat terutama dalam bidang kesehatan, hingga pada dampak ekonomi. Potensi Permasalahan yang muncul akibat COVID19 dan wajib diperhatikan Pemerintah Daerah, antara lain: Ketersediaan anggaran yang terbatas untuk penanganan COVID-19 dalam APBD TA 2020; Tidak tersedianya sarana dan prasarana kesehatan penanganan COVID-19; Ketidaksiapan tenaga medis dalam menghadapi COVID-19; Kurangnya jumlah tenaga medis dalam penanganan COVID-19; Ketersedian bahan pangan dan kebutuhan pokok yang terganggu akibat panic buying; Pekerja harian pelaku ekonomi tingkat bawah (pelayan restoran, ojek, pedagang kaki lima, dll) tidak dapat bekerja sehingga tidak mempunyai penghasilan; Adanya kemungkinan PHK bagi industri yang tutup; dan Potensi penerimaan APBD dari Jenis Pendapatan Asli Daerah (terutama pajak dan retribusi) tidak optimal dan Penyerapan APBD tidak maksimal karena dampak kebijakan Work from Home. 
Pemerintah melaksanakan langkah-langkah preventif antara lain optimalisasi sumberdaya yang tersedia, mencakup pembiayaan, sarana, dan prasarana dengan menggunakan APBD khususnya DAK kesehatan tahun 2020 serta Dana Desa untuk penanggulangan wabah COVID-19 dan mengoptimalkan potensi lokal/Optimalisasi potensi lokal yang dapat menjadi alternatif pemenuhan kebutuhan masyarakat, khususnya untuk pemenuhan kebutuhan pokok masyarakat. Di provinsi Jawa Timur, telah dikembangkan kawasan agropolitan sejak tahun 2015 dengan beberapa regulasi yang menitik beratkan pada pelaksanaan pengembangan kawasan agropolitan, dan yang kemudian disertai dengan kawasan minapolitan, dilandasi oleh arah RPJMD Provinsi Jawa Timur 2014-2019, yang memilik visi “Terwujudnya Jawa Timur Lebih Sejahtera, Berkeadilan, Mandiri, Berdaya Saing dan Berahlak". Oleh karena itu pengembangan kawasan agropolitan dan kawasan minapolitan ini kedepan (hingga tahun 2019) dijadikan bagian/alat pelaksanaan pencapaian misi pembangunan jangka menengah Jawa Timur, yaitu "Makin Sejahtera dan Mandiri bersama Wong Cilik” (Tim Penulis Pemprov Jawa Timur, 2019).

Penelitian ini bertujuan memberikan beberapa alternatif kebijakan untuk pemerintah daerah Jawa Timur dalam rangka penanganan dampak ekonomi yang disebabkan oleh persebaran COVID-19 khususnya di kawasan agropolitan. Penelitian ini mencoba menggali beberapa bukti literatur, dokumen, data sekunder, dan bukti fisik lainnya, dan mencoba mengkolaborasikan dengan fakta yang terjadi dan teori yang relevan, artikel ini menggunakan pendekatan studi literatur, yaitu penelitian yang menggunakan bahan-bahan pustaka tanpa melakukan riset lapangan, sehingga kegiatannya 
berkenaan dengan metode pengumpulan data pustaka, membaca, mencatat serta mengolah bahan penelitian menjadi sebuah formulasi hasil penelitian yang diharapkan oleh tujuan penelitian (Bungin, 2001). Pada akhir pembahasan penelitian ini membahas hasil analisis langkah optimalisasi potensi lokal daerah dalam upaya penanganan dampak ekonomi akibat pandemi COVID-19 adalah dengan mengatur ulang strategi pengembangan kawasan agropolitan yang telah ada dengan memperluas jangkauan kawasan ke daerah lain yang memiliki potensi di bidang agraris, dan memanfaatkan media dan platform online dalam pelaksanaan kegiatan yang dilakukan, diantaranya dalam hal permodalan dan pemasaran secara digital. hal tersebut juga tidak lepas dari usaha kolaborasi antar berbagai pihak serata penguatan regulasi, kelembagaan serta kemampuan/pengetahuan bagi pelaku dalam pengembangan kawasan agropolitan.

\section{TINJAUAN LITERATUR}

\section{Sekilas Tentang Corona Virus Desease 2019 (COVID-19)}

COVID-19 merupakan penyakit menular yang disebabkan oleh virus bernama SARS-COV-2, atau seringkali disebut Virus Corona. Virus Corona sendiri merupakan keluarga virus yang sangat besar. Infeksi terjadi pada hewan dan manusia (Tim Penulis Pemerintah Jawa Timur, 2019). Pada manusia biasanya menyebabkan penyakit infeksi saluran pernapasan, mulai flu biasa hingga penyakit yang serius seperti Middle East Respiratory Syndrome (MERS) dan Sindrom Pernapasan Akut Berat/Severe Acute Respiratory Syndrome (SARS). Penyakit ini menyebar melalui tetesan pernapasan dari batuk dan bersin. Virus ini dapat tetap bertahan hingga tiga hari dengan plastik dan stainless steel 
SARS CoV-2 dapat bertahan hingga tiga hari,atau dalam aerosol selama tiga jam. Virus ini juga telah ditemukan di feses, tetapi hingga Maret 2020 tidak diketahui apakah penularan melalui feses mungkin, dan risikonya diperkirakan rendah (Safrizal, 2020).

World Health Organization (WHO) menyatakan COVID-19 sebagai pandemi global, pernyataan resmi Presiden Republik Indonesia yang menyatakan penyebaran COVID-19 sebagai Bencana Nasional (Bencana Non-Alam) dan Keputusan Kepala Badan Nasional Penanggulangan Bencana (BNPB) terkait Perpanjangan Status Keadaan Tertentu Darurat Bencana Wabah Penyakit Akibat Virus COVID-19 di Indonesia. Pernyataan sebagai pandemi global merupakan suatu isyarat bahwa dalam menghadapi pandemi ini segala fokus kebijakan yang dilakukan suatu negara harus memprioritaskan kebijakan penanganan kesehatan dibandingkan kebijakan politik maupun ekonomi (Tim Penulis Pemerintah Jawa Timur, 2019).

\section{Dampak Akibat Pandemi COVID-19}

Terdapat beberapa dampak yang timbuL akibat adanya pandemi COVID-19 ini, diantaranya adalah: Bidang Pekerjaan, COVID-19 mengharuskan masyarakat untuk menjaga jarak aman baik dengan pembatasan sosial berskala besar, sistem bekerja dari rumah (work from home) hingga semi lockdown. Hal tersebut menyebabkan banyak masyarakat yang mengurangi tingkat konsumsi sebagai dampak kehati-hatian dalam bertindak semala masa pandemi, sehingga mengakibatkan adanya jumlah orang tidak bekerja lagi sejumlah 55\% laki-laki dan $57 \%$ perempuan di seluruh sektor dan beragai latar belakang pendidikan. 
Kerawanan Pangan, karena meningkatnya tingkat pengangguran yang terjadi sejak terjadinya pandemi dan menambah jumlah pengurangan tenaga kerja menyebabkan $23 \%$ masyaraat memiliki tingkat konsumsi seperti biasanya, dan 36\% masyarakat menurunkan tingkat konsumsi akibat penurunan kondisi tingkat keuangan.

Migrasi, Migrasi terjadi akibat tidak adanya lagi lahan pekerjaan bagi masyarakat karena pandemi, $38 \%$ laki-laki dan $31 \%$ perempuan telah melakukan migrasi sejak adanya krisis COVID-19, tingkat migrasi lebih tinggi terjadi pada msayarakat yang memiliki tingkat pendidikan SD ke bawah. Migrasi ini kebanyakan terjadi dari kota ke desa (daerah dimana para migran berasal).

Program Sosial Pemerintah, Program sosial pemerintah diadakan oleh pemerintah sebagai langkah untuk memberikan bantuan bagi masyarakat yang terdampak, terumata masyarakat miskin yang banyak kehilangan sumber penadapatan, sejumlah $20 \%$ laki-laki dan $16 \%$ perempuan menerima BPNT/Sembako/PKH, kemudian $27 \%$ laki-laki dan $21 \%$ perempuan menggunakan akses asuransi kesehatan pemerintah.

Data dibawah ini menunjukkan bahwa adanya program bantuan dari pemerintah membuat angka negatif menjadi berkurang, ini menandakan terdapat perubahan pada konsumsi masyarakat stelah adanya bantuan dari pemerintah. 


\section{Gambar 1.1}

Tingkat Perubahan Konsumsi/Kapita Masyarakat Sejak Pandemi COVID-19 (worldbank.org)

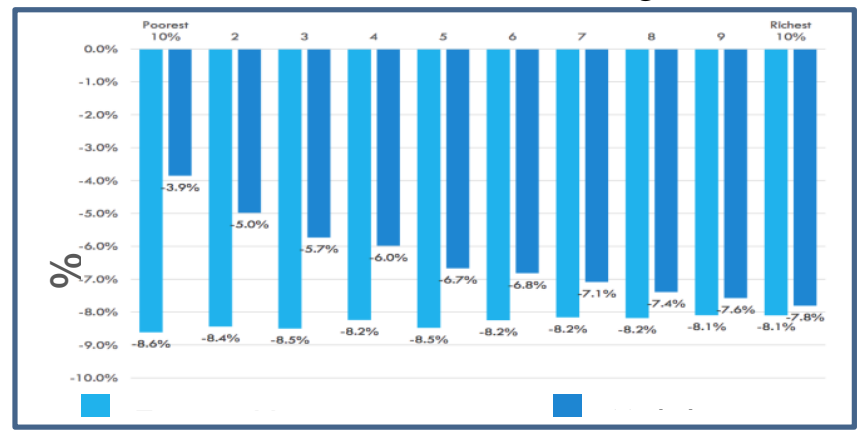

Pengetahuan dan Perilaku Kesehatan, era revolusi industri 4.0 yang mengakibatkan cepatnya arus informasi yang diterima oleh masyarakat memberikan informasi dan pengetahuan yang berkaitan dengan pandemi COVID-19 mulai dari pengetahuan terkait virus sampai pada pencegahannya, dan akhirnya mempengaruhi perilaku sanitasi yang meningkat secara pesat.

Peningkatan Jumlah Kriminalitas, Peningkatan tingkat kriminalitas yang terjadi disebabkan oleh beberapa sebab, diantaranya akibat kebijakan pemerintah pada pengurangan jumlah tahanan rutan dalam upaya pelaksanaan social distancing, dan desakan kebutuhan masyarakat akibat penurunan kemampuan keuangan yang dimiliki oleh masyarakat yang berakibat pada tindakan yang melanggar hukum, pada data data bulan april menunjukkan peningkatan angka kriminalitas sebesar 19,72\% (katadata.co.id). 


\section{Kebijakan Pemerintah Daerah dalam Penanganan Pandemi Covid-19}

Kebijakan bagi Pemerintah Daerah terkait percepatan Penanganan COVID-19 : (1) Peraturan Menteri Dalam Negeri No. 20 Tahun 2020 tentang Percepatan Penanganan COVID-19 di Lingkungan Pemerintah daerah; (2) Peraturan Bersama Menteri Dalam Negeri dan Menteri Keuangan Nomor 119/2813/SJ tentang Percepatan Penyesuaian Anggaran Pendapatan dan Belanja Daerah Tahun 2020 dalam Rangka Penanganan COVID-19 Serta Pengamanan Daya Beli Masyarakat dan Perekonomian Nasional; (3) Surat Edaran No. 440/2622/SJ tentang Pembentukan Gugus Tugas Percepatan Penanganan COVID-19 Daerah; (4) Instruksi Menteri Dalam Negeri Nomor 1 Tahun 2020; dan (5) Buku Pedoman Umum menghadapi Pandemi COVID-19 bagi Pemerintah daerah.

Gubernur dan Bupati/walikota menetapkan status siaga/darurat bencana dengan mempertimbangkan: (1) Berdasarkan pada kajian atau penilaian kondisi daerah penyebaran COVID-19; (2) Setelah dilakukan kajian atau penilaian kondisi daerah, Gubernur, Bupati/Walikota menetapkan status bencana COVID- 19; (3) Penyesuaian APBD tahun 2020 dilakukan dengan penyesuaian pendapatan Transfer ke Daerah dan Dana Desa, penyesuaian PAD dengan memperhitungkan potensi pajak daerah dan retribusi masing-masing daerah, rasionalisasi belanja pegawai, rasionalisasi belanja barang/jasa sekurang-kurangnya 50\% dengan mengurangi anggaran belanja, rasionalisasi belanja modal sekurang-kurangnya 50\% dengan mengurangi anggaran belanja.

Adapun Pengurangan penggunaan anggaran melalui: (1) Realokasi penggunaan anggaran honorarioum, bantuan sosial dan 
hibah kepada masayrakat miskin/kurang mampu; (2) Pemberian bantuan sosial kepada masyarakat miskin/ kurang mampu; (3) Penerapan pola padat karya tunai; (4) Penyesuaian pelaksanaan kegiatan yang mengundang orang banyak. Sedangkan penyesuaian anggaran ditujukan untuk : (1) Belanja bidang kesehatan dan hal lain terkait terkait pencegahan dan penanganan COVID-19; (2) Penyediaan jaring pengaman sosial; 3) Penanganan dampak ekonomi terutama agar dunia usaha tetap hidup (Tjenreng, 2020).

Percepatan alokasi anggaran dengan cara refocusing anggaran dan perubahan alokasi anggaran untuk penanganan COVID19 di daerah dilakukan melalui optimalisasi penggunaan Belanja Tidak Langsung (BTT), yang diprioritaskan untuk : (1) Penanganan Kesehatan, BTT digunakan untuk penyediaan sarana dan prasarana kesehatan, fasilitas kesehatan, perekrutan tenaga medis, pemberian disinfektan dan penyewaan rumah singgah isolasi, serta penanganan kesehatan lainnya; (2) Penanganan Dampak Ekonomi, Dilakukan dengan pengadaan bahan pangan dan kebutuhan pokok masyarakat, pemberian insentif, pemberian stimulus kepada UMKM dan penanganan dampak ekonomi lainnya; (3) Penyediaan Jaring Pengaman Sosial, dilakukan dengan memberikan Hibah/Bansos dalam bentuk uang dan/atau barang dari pemerintah daerah. Dalam Hal BTT tidak Mencukupi, pemerintah daerah dapat melakukan refocusing anggaran melalui pemanfaatan uang kas yang tersedia (Tjenreng, 2020).

Pemerintah Daerah memiliki peran penting untuk mengurangi persebaran dan mengantisipasi dampak COVID-19, sehingga Pemda didorong untuk terus melakukan monitoring daerahnya dengan 
beberapa langkah yaitu: Pencegahan penyebaran, Koordinasi dengan Forkopimda, organisasi masyarakat dan tokoh masyarakat untuk mengurangi persebaran COVID-19. Optimalisasi kegiatan, Pemerintah Daerah didorong untuk meningkatkan kapasitas penanganan kesehatan, dampak ekonomi dan pengamanan sosial. Memastikan kebutuhan masyarakat, Memastikan kecukupan sembako dan keberlangsungan industri di daerah. Penerapan inovasi daerah, Penerapan inovasi daerah untuk menjaga kestabilan ekonomi di daerah.

\section{Upaya Pemerintah dalam Penanganan Dampak Ekonomi Akibat} Covid-19

Akibat adanya pandemi COVID-19 yang terjadi, mengakibatkan munculnya permasalahan yang berdampak pada ekonomi global maupun lokal. Pemerintah Indonesia baik pusat, daerah serta stakeholder yang berkaitan berkolaborasi dalam merumuskan kebijakan untuk mengatasi dampak ekonomi tersebut, diantaranya adalah: 1) Pemerintah melalui Kementerian Keuangan dan Lembaga Ekonomi nasional lainnya telah menetapkan beberapa kebijakan untuk mengantisipasi dampak ekonomi dari COVID-19; 2) Kebijakan yang diambil telah mengakomodir dunia usaha, UMKM, Masyarakat Menengah dan Masyarakat Miskin; 3) Pemerintah daerah juga didorong untuk melakukan penanganan dampak ekonomi dengan cara pengadaan bahan pangan dan kebutuhan pokok dalam rangka menjaga ketahanan pangan daerah, pemberian insetif berupa pengurangan atau pembebasan pajak daerah, perpanjangan waktu pemenuhan kewajiban perpajakan, dan perpanjangan kewajiban 
pembayaran dana bergulir; 4) Pemberian stimulus berupa penguatan modal usaha kepada pelaku UMKM yang terkena dampak ekonomi akibat COVID-19.

Guna menjaga kestabilan ekonomi dan sosial di Indonesia, pemerintah juga menggalakkan program Jaring Pengaman Sosial diantaranya adalah dengan memberikan subsidi listrik bagi keluarga tidak mampu, kartu prakerja bagi pekerja yang terdampak PHK, kartu sembako, Program Keluarga Harapan, Bantuan Sosial Tunai, Bantuan Sosial Sembako, Bantuan Langsung Tunai dana desa, dan lain-lain. Pemerintah Daerah juga didorong untuk menyediakan jaring pengaman sosial melalui pemberian Hibah/Bansos dalam bentuk uang dan/atau barang, jaring pengaman sosial ini akan diberikan kepada Individu/masyarakat yang terdampak COVID-19 atau memiliki resiko sosial (seperti keluarga miskin dan pekerja informal), fasilitas kesehatan milik masyarakat/swasta yang ikut menanganani COVID-19 dan Instansi vertikal yang turut serta mendukung penanganan COVID19 (Tjenreng, 2020).

Secara umum usaha yang dilakukan pemerintah di dalam mencegah dampak ekonomi yang mengancam kesejahteraan masyarakat dilakukan secara menyeluruh, sebab jika dampak teknis pencegahan penyebaran COVID-19 belum dilaksanakan secara maksimal, maka dampak ekonomi juga tidak dapat diatasi dengan maksimal, maka pemerintah melaksanakan langkah-langkah preventif antara lain, (1) Secara konsisten melaksanakan instruksi penanganan COVID-19, Seluruh instruksi dari pemerintah dan pemerintah daerah terkait dengan penanganan COVID19 seperti PSBB dan penggunaan masker; (2) Optimalisasi sumberdaya yang tersedia, mencakup 
pembiayaan, sarana, dan prasarana dengan menggunakan APBD khususnya DAK kesehatan tahun 2020 serta Dana Desa untuk penanggulangan wabah COVID-19; (3) Mengoptimalkan potensi lokal, Optimalisasi potensi lokal dapat menjadi alternatif pemenuhan kebutuhan masyarakat, khususnya untuk pemenuhan kebutuhan pokok masyarakat; (4) Pengembangan inklusi keuangan, dengan cara Meningkatkan akses masyarakat terhadap layanan keuangan formal, khususnya masyarakat berpenghasilan rendah; (5) Peningkatan pelaksanaan upaya intervensi, Melalui kebijakan seperti relaksasi kredit dan bantuan permodalan diharapkan dapat berjalan tepat guna bagi masyarakat; dan (6) Peningkatan kolaborasi semua sektor terkait, Kolaborasi antara pemerintah, swasta, LSM, perguruan tinggi dan masyarakat sangat dibutuhkan baik untuk transfer informasi dan serta penerapan kebijakan (Tjenreng, 2020).

\section{Potensi Pengembangan Kawasan Agropolitan Di Jawa Timur}

Berdasarkan keputusan Direktorat Jenderal Tata Perkotaan dan Tata Perdesaan Tahun 2005, secara umum Program Agropolitan mengandung pengertian pengembangan suatu kawasan tertentu yang berbasis pada pertanian, dan dapat dilihat dari berbagai pengertian. Diantaranya, agropolitan adalah kota pertanian yang tumbuh dan berkembang, serta mampu memacu berkembangnya sistem usaha agribisnis, sehingga dapat melayani, mendorong, menarik, menghela kegiatan pembangunan pertanian di wilayah sekitarnya. Kawasan agropolitan terdiri dari kota pertanian dan desa-desa sentra produksi pertanian di wilayah sekitarnya, tanpa ditentukan oleh batasan 
administrasi pemerintahan, tapi lebih ditentukan dengan memperhatikan skala ekonomi yang ada.

Dalam konsep agropolitan juga diperkenalkan adanya agropolitan district, yaitu suatu daerah perdesaan dengan radius pelayanan 5-10 km, dan jumlah penduduk 50-150 ribu jiwa, serta kepadatan minimal 200 jiwa/km2. Jasa-jasa dan pelayanan yang disediakan disesuaikan dengan tingkat perkembangan ekonomi dan sosial budaya setempat. Agropolitan district perlu mempunyai otonomi lokal yang memberi tatanan terbentuknya pusat-pusat pelayanan di kawasan perdesaan telah dikenal sejak lama. Pusat-pusat pelayanan tersebut dicirikan dengan adanya beberapa untuk pelayanan masyarakat perdesaan.

Dalam hal ini agribisnis diartikan sebagai sebuah sistem, terdiri dari unsur-unsur kegiatan pra-panen, panen, pasca panen dan pemasaran. Sebagai sebuah sistem, kegiatan agribisnis tidak dapat dipisahkan satu sama lainnya, sebab harus saling menyatu dan saling terkait. Kalau terputus salah satu bagian, maka akan menyebabkan timpangnya sistem tersebut. Sedangkan kegiatan agribisnis mencakup sektor pertanian, termasuk perikanan dan kehutanan, serta bagian dari sektor industri. Usaha agribisnis memiliki kecenderungan menuntut untuk dikembangkan menjadi usaha dengan orientasi bisnis atau keuntungan. Hal ini dapat dilakukan melalui aplikasi konsep pengembangan berdasarkan sistem agribisnis terpadu. Potensi sumber daya alam yang tersebar tidak merata di setiap daerah, pengembangannya perlu dikaitkan dengan pengembangan wilayah nasional dan lokal, serta berpedoman pada Rencana Tata Ruang Wilayah Nasional (RTRWN), dan Rencana Tata Ruang Wilayah 
Provinsi (RTRWP) yang telah mengidentifikasikan kawasan andalan, kawasan prioritas pengembangan berikut jenis pengembangannya dalam menunjang pembangunan, yang berpotensi untuk meningkatkan PAD. Sasaran pengembangan kawasan agropolitan diantaranya untuk mengembangkan kawasan pertanian yang berpotensi menjadi kawasan agropolitan, melalui pemberdayaan masyarakat pelaku agribisnis agar mampu meningkatkan produksi, produktivitas komoditi pertanian, serta berbagai produk olahan pertanian. Semua itu dilakukan dengan pengembangan sistem dan usaha agribisnis yang efisiensi. Kemudian, penguatan kelembagaan petani, pengembangan kelembagaan sistem agribisnis (penyedia agroinput, pengelolaan hasil, pemasaran dan penyedia jasa), pengembangan kelembagaan penyuluhan pembangunan terpadu, pengembangan iklim yang kondusif bagi usaha dan investasi, serta peningkatan PAD berbasis pertanian dan multi sektor (Rachman, 2011).

Di Provinsi Jawa Timur, hingga awal tahun 2019 ini, gerakan Pengembangan Kawasan Agropolitan di Jawa Timur tercatat masih diikuti oleh 25 Kabupaten/Kota dan 2 Kabupaten yang masih dalam proses penetapan sebagai kawasan agropolitan yaitu Kabupaten Magetan. Dua puluh enam Kabupaten/Kota yang telah memiliki kawasan Agropolitan tersebut adalah Kota Batu, Kabupaten Mojokerto, Ngawi, Banyuwangi, Lumajang, Bangkalan, Tulungagung, Trenggalek, Pamekasan, Pasuruan, Madiun, Ponorogo, Blitar, Pacitan, Nganjuk, Probolinggo, Malang, Lamongan, Tuban, Bondowoso, Bojonegoro, Jombang, Sumenep, Sampang, Sidoarjo, dan Situbondo. Diharapkan pada tahun 2020 terdapat 29 Kabupaten/Kota di Jawa Timur dapat mengikuti gerakan Agropolitan atau setidaknya telah 
memiliki dokumen perencanaan kawasan Agropolitan yang memiliki kekuatan hukum (jatimprov.go.id).

\section{Strategi Pemasaran Online}

Internet digunakan setiap orang diseluruh dunia untuk saling bertukar informasi, menjadi sumber informasi dan juga menjadi sarana untuk membujuk konsumen. Internet marketing (pemasaran internet) menuntut adanya penguasaan aspek kreatif dan aspek teknis internet secara bersama-sama, mencakup desain, pengembangan, periklanan, dan penjualan. Media sosial memberikan kesempatan untuk berinteraksi lebih dekat antara berbagai pihak, seperti antara produsen dengan konsumen, media sosial dapat menjadi media untuk membentuk komunitas online. Media sosial dapat menjadi bagian dari keseluruhan e-marketing strategi yang digabungkan dengan media sosial lainya. Media sosial memberikan peluang masuk ke komunitas yang telah ada sebelumnya dan memberikan kesempatan mendapat feedback secara langsung (Puntoadi, 2011).

Brenda Kienan mengatakan bahwa E-marketing adalah melakukan bisnis online yang bentuknya paling jelas adalah menjual produk kepada konsumen secara online. Sederhananya adalah membuat, mengelola dan meluaskan hubungan komersial secara online. Oleh karena itu, untuk menunjang pernyataan diatas maka Goldman Sach berpendapat bahwa model bisnis dalam layanan bisnis online (E-marketing) terbagi atas 6 (enam) jenis, antara lain: (1) Connectivity, Bisnis yang berbasis layanan akses internet kepada pelanggannya; (2) Context, Bisnis yang memberikan layanan dengan berupa informasi dan hiburan; (3) Content, Bisnis yang memberikan 
layanan dengan basis berupa teks atau gambar sebagai inti bisnisnya; (4) Communication, Layanan komunikasi berbasis internet dengan menggunakan media interaktif; (5) Community, Bisnis yang membngun komunitas digital dengan media massage, board, web chat, maupun penyedia web mail; (6) Commerce, Model bisnis yang melakukan aktivitas bisnis berbasis internet (Immanuel, 2013). Saluran pemasaran online yaitu layanan online komersial, internet layanan yang menawarkan informasi dan layanan pemasaran online kepada pelanggan yang membayar biaya bulanan, seperti America online, Compuserve dan Prodig dan internet, web global jaringan komputer yang luas dan berkembang pesat yang tidak mempunyai manajemen dan kepemilikan sentral (Anonimous, 2010).

\section{METODE PENELITIAN}

Penelitian ini menggunakan metode penelitian studi literatur, data yang diperoleh dikompulasi, dianalisis, dan disimpulkan sehingga mendapatkan kesimpulan mengenai studi literatur. Dengan demikian penelitian studi literatur adalah sebuah penelitian yang dikategorikan sebagai sebuah karya ilmiah karena pengumpulan data dilakukan dengan sebuah strategi dalam bentuk metodologi penelitian. Variabel pada penelitian studi literatur bersifat tidak baku. Data yang diperoleh dianalisis secara mendalam oleh penulis, kemudian dituangkan ke dalam beberapa sub bab sehingga menjawab rumusan penelitian (Zed, 2014).

Pada penelitian mengambil data literatur dari beberapa sumber, diantaranya dari sumber naskah kebijakan, internet, konten seminar, dan sumber-sumber tertulis lainnya mengenai kebijakan dalam 
pemberdayaan ekonomi yang tepat diterapkan pada masa pandemik COVID-19.

\section{HASIL DAN PEMBAHASAN}

\section{Alternatif Kebijakan Penanganan Dampak Ekonomi COVID-19 di Jawa Timur}

Optimalisasi sumberdaya yang tersedia, mencakup pembiayaan, sarana, dan prasarana dengan menggunakan APBD khususnya DAK kesehatan tahun 2020 serta Dana Desa untuk penanggulangan wabah COVID-19. Dari dana tersebut baik pemerintah desa maupun kabupaten dapat memaksimalkannya untuk pelaksanaan protokol kesehatan, antisipasi kejadian yang tidak dapat diduga, kemudian penyaluran bantuan-bantuan yang telah ditetapkan oleh pemerintah pusat. Optimalisasi potensi lokal, Optimalisasi potensi lokal dapat menjadi alternatif pemenuhan kebutuhan masyarakat, khususnya untuk pemenuhan kebutuhan pokok masyarakat.

Di daerah Jawa Timur ini memiliki potensi dominan adalah di bidang agribisnis yang meliputi pertanian, peternakan, perkebunan dan kehutanan. Sesuai yang tertulis dalam RPJMD Jawa Timur 2018-2024 bahwa Salah satu poin dalam Sustainable Development Goals (SDGs) di Tahun 2016-2030 adalah Mengakhiri kelaparan, mencapai ketahanan pangan dan peningkatan gizi, dan mempromosikan pertanian berkelanjutan. Berkelanjutan disini artinya mempertahankan mutu promosi yang dapat meningkatkan penjualan baik dalam negeri maupun luar negeri dengan memanfaatkan teknologi berbasis pemasaran online. Dalam hal masa pandemi COVID-19, maka bagi daerah yang diberlakukan Pembatasan Sosial Berskala Besar (PSBB) 
akan merasakan dampak ekonomi paling dominan dibandingkan daerah lain. Laporan perkembangan penyebaran COVID-19 di Jawa Timur menunjukkan angka kematian $(9,69 \%)$ yang lebih tinggi dibandingkan dengan data nasional (6,51\%) (Baskoro, 2010).

Dalam Peraturan Menteri Kesehatan RI dengan data tersebut maka kebijakan PSBB akan sangat diperlukan. Pembatasan Sosial Berskala Besar (PSBB) adalah pembatasan kegiatan tertentu penduduk dalam suatu wilayah yang diduga terinfeksi Corona Virus Disease 2019 (COVID-19) sedemikian rupa untuk mencegah kemungkinan penyebaran Corona Virus Disease 2019 (COVID-I9). Untuk dapat ditetapkan Pembatasan Sosial Berskala Besar, suatu wilayah provinsi/kabupaten/kota harus memenuhi kriteria sebagai berikut: a) jumlah kasus dan/atau jumlah kematian akibat penyakit meningkat dan menyebar secara signifikan dan cepat ke beberapa wilayah; dan b) terdapat kaitan epidemiologis dengan kejadian serupa di wilayah atau negara lain.

Jawa timur merupakan provinsi kedua terbanyak kasus positif COVID-19, sehingga PSBB mulai banyak dilakukan di beberapa daerah di wilayah jawa timur. PSBB ini secara langsung akan berdampak negatif terhadap perekonomian daerah, terutama bagi para penggiat ekonomi UMKM, perusahaan, dan yang paling berdampak adalah pedagang-pedagang kecil yang menggantungkan biaya hidupnya dari penghasilan harian. Dengan diberlakukannya PSBB, maka tingkat konsumsi masyarakat akan banyak menurun, dikarenakan alasan protokol kesehatan serta banyak yang mengalihkan pengeluaran kepada kebutuhan yang dipandang lebih berdampak dalam pencegahan COVID-19 terutama suplemen dan peralatan kesehatan lainnya. Oleh 
karena itu diperlukan beberapa upaya pemerintah yang berkolaborasi dengan pihka-pihak terkait dalam memaksimalkan kebijakan penanganan dampak ekonomi yang terjadi, khususnya di wilayah Jawa Timur. Tujuan Pembangunan Jangka Panjang Provinsi (RPJPP) Jawa Timur tahun 2005-2025 adalah mewujudkan Provinsi Jawa Timur sebagai Pusat Agrobisnis Terkemuka, Berdaya Saing Global dan Berkelanjutan. Pengembangan Kawasan Agropolitan pada dasarnya sesuai dengan arah kebijakan dalam RPJPP Jawa Timur 2005 - 2025, yaitu arah kebijakan misi Mengembangkan Perekonomian Modern Berbasis Agrobisnis, yang antara lain meliputi transformasi sistem agrobisnis; pengembangan sistem informasi agrobisnis; pengembangan sumberdaya agrobisnis; pembinaan sumberdaya manusia; pengembangan fasilitas penelitian dan pengembangan pertanian, dan; penguatan struktur perekonomian (agropolitan.jatimprov.go.id).

Pemerintah daerah dalam penanganan dampak ekonomi akibat COVID-19 yaitu dengan cara mengoptimalkan potensi ekonomi lokal yang menjadi cara untuk pemenuhan kebutuhan masyarakat terutama kebutuhan pangan. Karena adanya PSBB dan protokol kesehatan yang harus dipatuhi, maka perkembangan teknologi di era revolusi industri 4.0 dapat dimanfaatkan semaksimal mungkin, sehingga alternatif yang dapat menjadi solusi dalam memaksimalkan potensi lokal di daerah Jawa Timur adalah dengan cara mengkombinasikan antara produkproduk yang dihasilkan dengan teknologi media sosial atau platform lain yang bisa digunakan sebagai strategi pemasaran online.

Beberapa daerah yang ada di provinsi Jawa Timur telah ditetapkan sebagai daerah kawasan agropolitan, diantaranya adalah Bojonegoro, Ngawi, Trenggalek, Mojokerto, Madura, Pasuruan, 
Jombang dan Probolinggo. Dalam perkembangannya kawasan agropolitan ini telah banyak menghasilkan tambahan bagi Pendapatan Asli Daerah, dengan memaksimalkan potensi daerah khususnya di bidang agribisnis. Berdasarkan peraturan pemerintah pusat maupun daerah, prospek dari pengembangan kawasan agropolitan ini sangat bagus dilihat dari perkembangan yang dicapai, sehingga dilihat dari laporan perkembangan masing-masing kawasan menunjukkan adanya penambahan program dan produk yang dipasarkan kepada masyarakat. Pada masa pandemi COVID-19 ini tentunya menjadi salah satu kendala bagi proses pemasaran yang dilakukan. Oleh karena itu dengan memaksimalkan fungsi dari perkemabngan teknologi melalui pemasaran online baik melalui, media sosial, media televise, media cetak, dan platform yang telah beredar di masyarakat, akan menjadi salah satu solusi bagi kelancaran proses pemasaran terutama untuk produk-produk yang dihasilkan dari kawasan agropolitan.

Berdasarkan data yang ada, masih banyak sekali kawasan yang berpotensi di bidang agribisnis yang masih belum dikembangkan menjadi kawasan agropolitan, seperti Magetan, Ponorogo, Tulungagung, lamongan, dan berbagai daerah lain yang ada di Jawa Timur. Beberapa langkah yang bisa dikembangkan dalam memaksimalkan potensi daerah di Jawa Timur adalah sebagai berikut:

1. Memaksimalkan sasaran dan tujuan bagi kawasan agropolitan yang telah tercantum dalam Keputusan Gubernur No. 188/40/KPTS/013/2015 tanggal 20 Januari 2015 tentang Kelompok Kerja (POKJA) Pengembangan Kawasan Agropolitan dan Minapolitan Provinsi Jawa Timur 2015. Sebagaimana yang dijelaskan bahwa konsep agropolitan adalah sebuah kebijakan 
pemerintah pusat yang merupakan pendekatan terpadu dari beberapa departemen bidang ekonomi untuk pembangunan di pedesaan (khususnya pertanian) dengan jalan melengkapi infrastruktur, memperluas akses terhadap kredit usaha untuk meningkatkan pendapatan petani dan mendorong pertumbuhan industri guna meningkatkan nilai tambah sektor pertanian. Program ini dirancang dan dilaksanakan dengan jalan mensinergikan berbagai potensi yang ada untuk mendorong berkembangnya sistem dan usaha agribisnis yang berdaya saing, berbasis kerakyatan, berkelanjutan dan terdesentralisasi (Kementerian pertanian.go.id). Pada era pandemi tentu banyak sasaran dan tujuan yang direncanakan akan terkendala dengan protokol kesehatan, sehingga untuk kegiatan yang tidak dapat dilaksanakan, bisa dialihkan ke alternatif kegiatan yang aman dan efektif, contohnya jika dalam bidang perkebunan buah dan sayuran, dapat mengalihkan ke sistem pertanian hidroponik, aeroponik, tanaman buah dalam pot, mengkombinasikan berbagai sistem/sistem pertanian terpadu (Integrated Bio Cycle Farming) dan sistem pertanian lain yang tidak membutuhkan lahan khusus. Sistem pertanian terpadu merupakan sistem yang menggabungkan kegiatan pertanian, peternakan, perikanan, kehutanan dan ilmu lain yang terkait dengan pertanian dalam satu lahan, sehingga diharapkan dapat sebagai salah satu sousi bagi peningkatan produktivitas lahan, program pembangunan dan konversi lingkungan, serta pengembangan desa secara terpadu. Diharapkan kebutuhan jangka pendek, menengah, dan panjang petani berupa pangan, sandang dan papan akan tercukupi dengan sistem 
pertanian ini, diharapkan petani/kelompok tani akan menjadi subyek dalam pelaksanaan kegiatan usaha tani tanpa tergantung dari pihak manapun dengan pembentukan permodalan dan pasar yang baik oleh lembaga atau instansi yang berkompeten (Artaji, 2015).

2. Penguatan regulasi tertulis oleh pemerintah dalam penguatan kelembagaan bagi kawasan-kawasan aagropolitan baru, agar keberdaannya menjadi legal dan mudah dalam mendapatkan berbagai akses ke semua pihak yang berpotensi untuk membuat jaringan, telah terbit beberapa aturan dari pemerintah pusat dan pemerintah daerah mulai dari Undang-Undang, Peraturan Pemerintah, Peraturan Menteri Dalam Negeri dan Peraturan Daerah yang menguatkan pelksanaan pengembangan kawasan agropolitan, dan diperlukan perturan baru bagi kawasan baru yang perlu untuk dikembangkan di era pandemi, sehingga akan memudahkan bagi beberapa daerah di jawa timur dalam mengakses segala hal yang berkaitan dengan pengembangan tersebut. permintah perlu mempermudah penerbitan regulasi terkait penambahan kawasan tersebut.

3. Peningkatan kerjasama antara pemerintah pusat dan daerah, lembaga keuangan, BUMN, Lembaga Swadaya Masyarakat, Kelompok-kelompok tani, dan semua pihak terkait untuk maksimisasi pencapaian tujuan dan sasaran yang telah ditetapkan. Kolaborasi yang terintegrasi akan memudahkan bagi para pelaku agropolitan di dalam melaksanakan tugas dan kegiatannya dalam memenuhi segala kebutuhan demi kelancaran kegiatan yang telah dirumusakan bersama-sama. 
4. Diversifikasi produk, diversifikasi produk adalahsebagai upaya mencari dan mengembangkan produk atau pasar baru, atau keduanya, dalam rangka mengejar pertumbuhan, peningkatan penjualan, profitabilitas dan fleksibilitas (Tjiptono, 2008). Jadi diversifikasi produk adalah suatu kebijakan dalam strategi perusahaan untuk memenuhi selera dan kebutuhan konsumen melalui penganekaragaman produk dalam rangka mengjar pertumbuhan, peningkatan penjualan, profitabilitas dan fleksibilitas dengan cara menciptakan produk atau jasa baru tanpa bergantung pada satu jeis produk, semakin beragam produk yang ditawarkan akan semakin menarik bagi konsumen untuk membeli produk yang ditawarkan (Hermawan, 2015).

5. Digitalisasi pemasaran, pemasaran digital adalah suatu usaha untuk mempromosikan sebuah merek dengan menggunakan media digital yang dapat menjangkau konsumen secara tepat waktu, pribadi dan relevan (Wikipedia.org). Kegiatan pemasaran Internet umumnya meliputi atau berkisar pada hal-hal yang berhubungan dengan pembuatan produk periklanan, pencarian prospek atau pembeli dan penulisan kalimat-kalimat pemasaran atau copywriting. Pemasaran internet atau e-pemasaran ini secara umum meliputi kegiatan pembuatan desain web (web design), periklanan dengan menggunakan banner, promosi perusahaan lewat mesin pencari informasi (search engine), surat elektronik atau e-surat (e-mail), periklanan lewat e-surat (email advertising), pemasaran afiliasi (affiliate marketing), advertensi interaktif (interactive advertising), dan lain-lain (Wandayana, 1978). Produk yang telah dihasilkan oleh kawasan agropolitan tidak hanya bisa dipasarkan secara 
offline, tapi memanfaatkan berbagai media pemasaran digital yang tersedia. Dengan demikian kontak langsung dalam pemasaran produk akan dapat dihindari dan tetap mematuhi protokol kesehatan. Produk yang akan dipasarkan tentunya tetap harus disterilisasi terlebih dahulu sebelum dikirimkan kepada konsumen. Cara ini akan dapat mempertahankan tingkat permintaan yang terkendala dengan adanya peraturan tentang pandemi COVID-19.

6. Peningkatan kegiatan edukasi bagi semua pelaku yang terkait dalam program dan masyarakat umum yang belum tergabung dalam program melalui media online selama pandemi dan dilanjutkan melalui media offline apabila pandemi telah berakhir. Banyak pelaku program di kawasan agropolitan yang masih perlu peningkatan sumber daya manusia dalam melaksanakan diversifikasi produk, karena banyak petani yang masih menggunakan teknologi lama yang belum mendukung perkembangan teknolog. Oleh karena itu dengan mengadakan kerjasama dengan beberapa perusahaan IT diharapkan akan dapat memberikan pelatihan dan edukasi kepda masyarakat untuk mengaplikasikan pemasaran digital. Selain itu untuk kawasan baru agropolitan, pemerintah daerah perlu melakukan sosialisasi online untuk memberikan arahan terkait pelaksanaan sistem kawasan agropolitan, dan untuk proses tersebut koordinasi dengan pemerintah setempat sangat diperlukan. Edukasi ini juga bisa berisi tentang pengelolaan sistem pertanian tanpa lahan atau pertanian yang menggunakan lahan di sekitar rumah, dan juga terobosanterobosan sistem pertanian yang dapat mendukung protokol kesehatan COVID-19. 
7. Peningkatan kemudahan akses permodalan, baik dari instansi pemerintah maupun non pemerintah dengan skema tertentu melewati lembaga keuangan bank maupun non bank. Berdasarkan kasus yang terjadi beberapa lembaga keuangan tidak mudah mengucurkan dana kepada petani yang ingin mengajukan modal untuk menjalankan bisnis pertanian mereka. Hal tersebut dikarenakan petani kurang mendapatkan kepercayaan dari sektor perbankan karena memiliki risiko yang tinggi (www.pioneer.com). Hal tersebut sangat disayangkan mengingat peluang usaha dari bisnis pertanian sangat besar dan tidak akan pernah menurun karena manusia selalu membutuhkan makanan yang bersumber dari bidang pertanian. Salah satu solusi untuk permodalan ini adalah dengan memanfaatkan fintech pertanian, sehingga petani dapat mudah mengakses permodalan secara online atau melewati pokja yang telah dipilih melalui surat keputusan gubernur. Pemerintah dapat membuat sebuah platform fintech untuk permodalan di bidang pertanian khusus untuk kawasan agropolitan, dengan sistem yang terintegrasi, maka diharapkan siklus bisnis di kawasan agropolitan dapat berjalan tanpa ada hambatan dan kendala.

\section{KESIMPULAN}

Penyebaran virus COVID-19 di Indonesia telah menimbulkan berbagai dampak, mulai dari dampak kesehatan hingga dampak ekonomi, dampak ekonomi menyebabkan pemerintah melakukan langkah-langkah penanganan dengan memebentuk satuan tugas penanganan penyebaran COVID-19 dan membuat beberapa regulasi 
dalam menghadapi pandemi yang berlangsung, diantaranya dengan menetapkan protokol kesehatan dan Pembatasan Sosial Berskala Besar (PSBB), yang menyebabkan menurunnya kegiatan ekonomi masyarakat.

Langkah pemerintah daerah dalam menangani dampak ekonomi adalah dengan optimalisasi potensi ekonomi lokal. Provinsi Jawa Timur memiliki potensi yang baik di bidang agraris, sehingga dengan program pengembangan kawasan agropolitan, merupakan salah satu potensi yang perlu dikembangkan lebih jauh, mengingat kebutuhan akan makanan adalah menjadi faktor utama untuk kelangsungan hidup masyarakat.

Beberapa langkah yang bisa dilakukan untuk memaksimalkan potensi kawasan agropolitan di tengah pandemi COVID-19 adalah dengan cara memaksimalkan sasaran dan tujuan bagi kawasan agropolitan yang telah tercantum dalam Keputusan Gubernur No. 188/40/KPTS/013/2015, penguatan regulasi tertulis oleh pemerintah, peningkatan kerjasama antara pemerintah dengan semua pihak terkait, diversifikasi produk, digitalisasi pemasaran, peningkatan kegiatan edukasi dan peningkatan kemudahan akses permodalan. Namun penelitian masih perlu dilakukan untuk membuktikan apakah solusi tersebut benar-benar berjalan efektif ataukah tidak untuk tercapainya tujuan yang diharapkan. 


\section{REFERENSI}

Anonimous. (2010). Pemasaran Langsung dan Online. gunadarma.ac.id.

Artaji, Windi. (2015). Sistem Pertanian Terpadu-Model pertanian Terpadu dan Satu Siklus Biologi (Integrated Bio Cycle Farming). kompasiana.com

Baskoro, Agung Hari. (2020). Jatim Provinsi di Luar Episentrum yang Tingkat Kematiannya Lebih Tinggi dan Kesembuhan Lebih Rendah Disbanding Nasional. Suarasurabaya.net.

Bungin, Burhan. (2011). Metodologi Penelitian Kulaitiatif. Raja Grafindo.

Entang Saeful Rachman, (2011). Kawasan Agropolitan Adalah Kawasan Agribisnis yang Memiliki Fasilitas Perkotaan,” Harapan Rakyat Online (blog.

Hermawan, Lucius. (2015). Dilema Diversifikasi Produk”. Jurnal Studi Manajemen, Vol. 9, No. 2.

Hikmah, Andi Ully. (2015). Pemberdayaan Ekonomi Masyarakat dari Desa Tertinggal Menuju Desa Tidak Tertinggal, Jurnal Administrasi Publik, Volume 2, Nomor 12.

Imanuel, Orland Jorge. (2013). Analisis Keputusan Pembelian Konsumen Melalui Media Online (E-Marketing)" 4.

Nadzir, Mohammad. (2015) Membangun Pemberdayaan Ekonomi di Pesantren," Economica: Jurnal Ekonomi Islam 6, no. 1.

Peraturan Menteri Kesehatan Republik Indonesia Nomor 9 Tahun 2020 Tentang Pedoman Pembatasan Sosial Berskala Besar 
Dalam Rangka Percepatan Penanganan Corona Virus Disease 2019 (Covid-19).

Puntoadi, Danis. (2011). Menciptakan Penjualan via Social Media. Elex Media Komputindo.

Safrizal ZA. (2020). Pedoman Umum Menghadapi Pandemi COVID-

19 Bagi Pemerintah Daerah. Jakarta: Kementerian Dalam Negeri.

Suharto, Edi. (2005). Membangun Masyarakat, Memberdayakan Rakyat. PT. Refika Aditama.

Tjenreng, M. Zamzami B. (2020). Kebijakan Pemerintah Dan Pemda

Dalam Penanganan Covid-19 Serta Pengaruhnya Bagi Ekonomi Nasional", dipresentasikan dalam webinar: ARS University. Yogyakarta.

Tjiptono, Fandy. (2008). Strategi Pemasaran.Penerbit Andi.

Tim Penulis UGM. (2020). Buku Saku Desa Tangguh COVID-19. UGM Press.

Tim Penulis. (2020). Protokol Percepatan Penanganan Pandemi COVID-19 (Corona Virus Disease 2019). Jakarta:Gugus Tugas Percepatan Penanganan COVID_19.

Tim Penulis Pemerintah Jawa Timur. (2019). Rencana Pembangunan Jangka Menengah Daerah (RPJMD) Provinsi Jawa Timur Tahun 2019-2024. Pemerintah Provinsi Jawa Timur.

Wandanaya, Anita B, (1978). Pengaruh Pemasaran Online Terhadap Keputusan Pembelian Produk.

Zed, Muhammad. (2014). Metode Penelitian Kepustakaan. Yayasan Obor Indonesia. 